\title{
Schedule of responsibilities and the assignment of files at Civil Courts in Tanzania
}

\author{
By Magdalena Sylister*
}

THEME: REQUIREMENTS FOR AN INDEPENDENT AND EFFECTIVE JUDICIARY IN BURUNDI, DR CONGO, KENYA, RWANDA, TANZANIA AND UGANDA - CURRENT PROBLEMS IN CRIMINAL AND CIVIL PROCEEDINGS

\section{A. ABStract}

This paper has looked at salient features of schedules of responsibilities of judicial officers in Tanzania and how assignment of files to those officers takes place. In doing that, the paper has focused on civil courts only so as to explore the topic in details. The main aim is to highlight current problems associated with those aspects. In view of that, the paper has relied on recent literature largely from Tanzania such as books, journal articles, reports, and website materials.

This work begins with an overview of the Tanzanian judicial structure for civil matters, followed by a highlight of factors determining schedule of responsibilities and the assignment of files in civil courts in Tanzania. Five major factors have been discussed, namely, legal requirements, size of the workload, size of the workforce, political factors and expertise. In the course of that discussion, the paper has identified and analysed current problems facing schedules of responsibilities and assignment of files in Tanzanian civil courts. Lastly, this paper has recommended viable measures for addressing those problems so as to improve effectiveness and independence of the Tanzanian judiciary.

\section{B. INTRODUCTION}

I would like to begin by profoundly thanking Professor Dr. Hartmut and Konrad Adenauer Stiftung for the prestigious and exciting opportunity to participate in this special conference. I say danke schon.

Also, I commend the structure of the presentations and discussions which has broken down the theme of the conference into specific topics. The approach will be very beneficial since it will facilitate an in-depth discussion of all the relevant issues revolving around the theme of the conference.

* Tanzanian, Advocate and Partner at Matrix Attorneys, Arusha, Tanzania; LL. M. (Distinction), University of Dar es salaam, Tanzania in association with the University of Bayreuth, Germany; LL. B. (Hons), University of Dar es salaam; Executive Director of the Foundation for Research and Assistance in Law; Advocate of the High Court and courts subordinate thereto save for primary courts, magdalenasylister@gmail.com. 
Going now to my presentation, this paper is about Schedule of Responsibilities and Assignment of Files in Civil Courts in Tanzania. In discussing that topic, the paper has started with a brief overview of the Tanzanian judicial structure for civil matters so that the main part of the paper may be well understood. Next, the paper has looked at how the schedule of responsibilities and assignment of files in civil courts in Tanzania takes place, factors that determine those two issues, challenges involved and how those matters relate to the theme of the conference.

\section{AN OVERVIEW OF THE TANZANIAN JUDICIAL STRUCTURE FOR CIVIL MATTERS}

The Tanzanian judicial structure is divided into what may be basically referred to as the main structure and the parallel bodies. To start with the main structure, at the bottom there is the primary court followed by a district court and then the resident magistrate's court (RMs court).

Adjudicators in those courts are referred to as magistrates. The district court and the RMs courts are generally considered to be of almost equal ranking although the resident magistrate's court has some extra jurisdiction and powers. The next immediate higher body is the High Court of Tanzania and above it there is the Court of Appeal, which is the highest judicial body in Tanzania. Adjudicators in those courts are known as judges. A judge in Tanzania is a very senior person both in terms of age and experience. Additionally, those courts have registrars and deputy registrars.

Parallel to that system, there are specialised bodies for commercial, land, together with employment and labour matters. To start with commercial disputes, there is a High Court Commercial division which deals with commercial cases only. With regard to employment and labour matters, the first body at the foot of the hierarchy is the commission for mediation and arbitration (CMA) whose level is almost equivalent to the district court. The CMA is presided over by a mediator and an arbitrator. Above the CMA there is the Labour Court which is the division of the High Court for employment and labour matters.

On land matters, at the lowest level we have the Ward Tribunal which is presided over by members of the Tribunal. Next there is the district land and housing tribunal (DLHT) which is almost equivalent to a district court and presided overby a chairperson. Above that body there is the High Court. There are other specialised judicial bodies such as for tax matterset cetera, but the ones mentioned above are sufficient for purposes of this discussion.

\section{FACTORS DETERMINING SCHEDULE OF RESPONSIBILITIES AND THE ASSIGNMENT OF FILES}

The primary duty of the judiciary is to dispense justice and it involves three key tasks. The first task is determination of main disputes including any related miscellaneous matters, the 
second one is ensuring execution of decisions and the third one is deciding taxation causes so as to enable parties who have been awarded costs to get hold of those costs. A feasible schedule of responsibilities and assignment of files is imperative so as to ensure that the duty is discharged satisfactorily. The schedule of responsibilities and assignment of files within the judiciary is determined by the following key factors:-

\section{Legal requirements.}

Primarily, responsibilities of a judicial officer are determined by Constitution, statutes, internal regulations and other legal instruments. In magistrate's courts, adjudication of main disputes is done by all magistrates but execution applications and taxation causes are done by magistrates in charge. In the District Land and Housing Tribunals, all chairpersons carry those three tasks. In the CMA arbitrators and mediators determine main disputes only while execution is done by registrars and deputy registrars of the Labour Court. Also, there are almost no taxation causes before the CMA because generally those bodies hardly award costs, even though the law empowers them to award costs if a party acts in a frivolous or vexatious manner. ${ }^{1}$ In higher courts, adjudication of main disputes is done by judges while execution and taxation matters are determined by registrars.

The implication thereof is that, some judicial officers such as judges and registrars have better schedules of responsibilities because there is a clear division of labour and that makes dispensation of justice more effective. Conversely, judicial officers such as the chairpersons of the District Land and Housing Tribunal have too many responsibilities and that jeopardises effectiveness of those officers.

Assignment of files is generally done by the leaders of the courts ${ }^{2}$ namely magistrates in charge in the case of magistrate's courts, arbitrators in charge in the case of CMA, judges in charge in the case of the High Court and the Chief Justice in the case of the Court of Appeal.

\section{Size of the workload.}

Workload can be defined as the amount of a particular type of work which a qualified person can handle within a determined time. ${ }^{3}$ On assignment of responsibilities, a clear measure of the Court workload is central in determining how many judicial officers are needed

1 For instance Rule 34(1) of the Labour Institutions (Mediation and Arbitration) Rules, 2007, Government Number 7 of 2004, provides that the arbitrator may make an order for costs in an arbitration in terms of Section $88(8)$ of the Employment and Labour Relations Act, if a party or person representing a party acted in a frivolous or vexatious manner.

2 Including other judicial bodies discussed herein.

3 Robert $V$. Makaramba, The Practical and Legal Challenges of Justice Delivery in Tanzania: Experience from the Bench,p. 17, www.comcourt.go.tz/comcourt/?wpfb_dl=37(last accessed on 14/08/2016). 
to resolve all the cases coming before the court. ${ }^{4}$ When the workload is huge, obviously a judicial officer will have more responsibilities and more files to adjudicate. According to the Tanzanian judiciary report of the 2014/2015 financial year, there has been a rapid increase of new disputes in courts due to improvements in legal services caused by an increase in the number of private advocates, activists and legal aid institutions. Those changes have enabled the people to have more legal knowledge and to demand their rights through court actions thereby leading to a rise in the workload of cases in courts. ${ }^{5}$

A good illustration is the District Land and Housing Tribunal of Arusha. In November, 2015, the Tribunal had 890 pending matters. In December, 2015 alone 78 new matters were filed, and for that month alone the Tribunal managed to finalise only 84 matters! ${ }^{6}$ Due to that backlog, it is very common for a case for hearing to be adjourned at an interval of 4 to 6 months. That means a case will appear before the Tribunal for hearing about only twice or thrice a year.

\section{Size of the workforce.}

Logically, when the size of the workforce is enough, responsibilities and files will be well distributed, and work will be done more efficiently. On the other hand, when the workforce is small, the judicial personnel will be overworked and that will most likely lead to inefficiency. Disputes will take too long to be completed and sometimes work will be done under too much pressure or below standards. The number of judges and magistrates has a direct impact on provision of justice in the country. ${ }^{7}$ The smaller the number means that fewer cases will be dealt with hence justice delayed, which in the long run would mean justice denied. ${ }^{8}$

Tanzania has made significant efforts to constantly increase the number of judicial officers but still in some areas the available workforce is still very insufficient. The Human Rights Report of Tanzania Mainland, $2010^{9}$ observes that there is scarcity of judicial officers in rural areas and that makes it very difficult for common citizens to access justice. ${ }^{10}$ In

4 Makaramba, note 5, p. 16.

5 Judiciary of Tanzania, Taarifa ya Mwaka ya Utekelezaji wa Majukumu Ya Mahakama Mwaka wa Fedha 2014/15 ya Tarehe 30 October, 2015, p. 22, http://www.judiciary.go.tz/wp-content/uploads/ 2016/08/TAARIFA-YA-MWAKA-YA-UTEKELEZAJI-2014.15-KATTANGAH-VERSION.pd f(last accessed on 15/08/2016).

6 Hotuba ya Chama cha Mawakili Tanganyika, Kanda ya Arusha katika Sikuya Sheria Tanzania, Tarehe 4 February, 2016.

7 Legal and Human Rights Centre, Tanzania Human Rights Report 2015, Tanzania Mainland, Legal and Human Rights Centre: Dar es salaam, p. 49.

8 Note 7.

9 Prepared by the Legal and Human Rights Centre.

10 Legal and Human Rights Centre, The Human Rights Report of Tanzania Mainland, 2010, Legal and Human Rights Centre: Dar es salaam p. 58. 
2014 it was observed that for the High Court to perform properly it requires 120 judges but by 2015 the Court had 83 judges only, making a deficit of 37 judges. ${ }^{11}$

In the Labour Court, Arusha registry, although there are many labour matters pending before that Court, and new ones continue to be filed, still the Court has no single resident judge or registrar while the main High Court, Arusha registry has about 5 resident judges and one resident registrar. The practice of the Labour Court has been that a judge and a registrar would go to Arusha on special sessions. Those sessions take place about twice or three times a year only and they would last for about three to four weeks. Also, the sessions are usually handled by only one judge and one registrar meaning that those persons get extremely overworked.

\section{Political factors.}

There are situations where political factors have a role to play in the discharge of judicial functions especially on assignment of cases and their determination. Before demonstrating how that happens, it is worth noting that in principle, the court is expected to be an impartial, fair institution, ${ }^{12}$ apolitical, and its symbol being that of a blind folded justice holding balanced scales. ${ }^{13}$ Tanzania has strived to maintain an independent and impartial judiciary but there are situations where political interests have compromised those efforts.

The fact that the executive has enormous powers on judicial appointments means that it can even somehow control how files are assigned within the judiciary so as to procure favourable outcomes. The President is vested with powers of appointment, control of discipline and removal of judges from office, appointments, confirmation, disciplinary and removal of Registrar of the Court of Appeal and the High Court. ${ }^{14}$ Furthermore, the judiciary is exposed to political pressure regarding which cases to consider and how to work on them. ${ }^{15}$ Rachel comments that in the presence of political insecurities generated through competitive elections, African leaders frequently manipulate and interfere with the Courts ${ }^{16}$ and that political elites seek to constrain or interfere with the judiciary through a range of

11 Note 7.

12 Amani Abeid Karume, The Courts of Law Should be Impartial and Fair Institutions, in Maina, C. P., and Kijo-Bisimba, H., (eds.), Law and Justice in Tanzania: Quarter of a century of the Court of Appeal, Dar es salaam, 2007, p. 45.

13 Note 12.

14 Legal and Human Rights Centre, Tanzania Human Right Report, 2012, Legal and Human Rights Centre: Dar es salaam, p. 42.

15 Bertelsmann Stiftung, Tanzania Country Report, p. 11, https://www.bti-project.org/fileadmin/files/ BTI/Downloads/Reports/2016/pdf/BTI_2016_Tanzania.pdflast accessed on 15/08/ 2016.

16 Rachel Ellet, Judicial Independence Under the APRM: From Rhetoric to Reality, Occassional Paper, 2015, 212, p. 7, http://www.saiia.org.za/occasional-papers/756-judicial-independence-under-t he-aprm-from-rhetoric-to-reality/file(last accessed on 20/08/2016]. 
strategies such as manipulating institutional design, engineering judicial appointments and redirecting the rules of the game. ${ }^{17}$

All that translates to political influence and it can be manifested in various forms such as where the executive chooses whether directly or indirectly, the judge to adjudicate a certain case, or a judicial officer to discharge certain responsibilities in which the executive is interested. Indicators which can assist to highlight existence of that influence include presence of some judges who were appointed unprocedurally, namely without being recommended nor vetted by the Judicial Service Commission, ${ }^{18}$ and judges employed on contractual basis after retirement. ${ }^{19}$ Those indicators suggest that the judges in questionmight have been placed in office for specific purposes and some day they would return the favour to the one who appointed them.Moreover, it has been noted that the Tanzanian High Court has rendered several bold decisions that have challenged the government but the Court of Appeal has often overturned those decisions. ${ }^{20}$ That trend by the Court of Appeal to some extent may offer another indication of political influence in the judiciary. One may argue that probably those files are assigned strategically to some personnel so that they may uphold interests of the executive.

\section{Expertise}

In some occasions, expertise of a judge is a criteria for assignment of files whereby a judge is assigned a case which is within his area of proficiency. That is a very positive practice because it guarantees maximum efficiency and it strengthens the jurisprudence. For example, as Professor Shivji observes, many of decisions by Justice Barnabas Albert Samatta, as he then was, especially at the bench of the Court of Appeal, are in criminal cases and that may have been because of his expertise in criminal law. ${ }^{21}$ Similarly, by reading various judgments and rulings, one can easily observe that the judge who delivered that judgment or ruling is fully proficient in the legal issues involved. However, there are situations where that criteria is not fully observed whereby files are assigned to persons who have no much expertise in the legal issues in dispute thereby reducing the quality of judicial decisions delivered thereto and making no or little contribution into the development of country's jurisprudence.

17 Note 16.p. 9.

18 Tundu Lissu, A statement on various issues regarding the Tanzanian judiciary, 2012, http://www.ja mhurimedia.co.tz/ripoti-maalumu/(last accessed on 19/08/2016).

19 Note 18.

20 Ellet, note 16, p. 24, http://www.saiia.org.za/occasional-papers/756-judicial-independence-under-t he-aprm-from-rhetoric-to-reality/file(last accessed on 20/08/2016].

21 Issa Shivji, and Hamudi Majamba, Justice Samatta's Road to Justice: An Introduction, in Issa Shivji and Hamudi Majamba, (eds.), Rule of Law vs. Rule of Law, Justice Barnabas Albert Samatta's Road to Justice, Dar es salaam, 2011, p. 3. 


\section{E. CONCLUSION AND RECOMMENDATIONS}

The challenges discussed above significantly inhibit successful scheduling of responsibilities and assignment of files within the judiciary thereby greatly compromising efforts that are being made to ensure independence and effectiveness of the Tanzanian judiciary. The following are recommended solutions:-

First, the laws which apportion too many responsibilities to judicial officers should be reformed so as to reduce that burden of responsibilities.

Secondly, there is a need for increasing the number of competent and qualified judicial officers so as to ensure that the judiciary is adequately staffed.

Thirdly,political influence within the judiciary should be eliminated and the judiciary should absolutely refuse to be used in furtherance of any political ambitions. In connection to that, the powers of the executive in judicial appointments and disciplining should be greatly reduced.

Fourthly, expertise should increasingly be relied upon as one of the crucial criteria in assignment of files.

\section{BIBLIOGRAPHY}

\section{BOOKS, REPORTS AND JOURNALS}

Amani Abeid Karume, The Courts of Law Should be Impartial and Fair Institutions, in Maina, C. P., and Kijo-Bisimba, H., (eds.), Law and Justice in Tanzania: Quarter of a century of the Court of Appeal, Dar es salaam, 2007.

Issa Shivji, and Hamudi Majamba, Justice Samatta's Road to Justice: An Introduction, in Issa Shivji and Hamudi Majamba, (eds.), Rule of Law vs. Rule of Law, Justice Barnabas Albert Samatta's Road to Justice, Dar es salaam, 2011.

Legal and Human Rights Centre, Tanzania Human Right Report, 2012, Legal and Human Rights Centre: Dar es salaam.

Legal and Human Rights Centre, Tanzania Human Rights Report, 2015, Tanzania Mainland, Legal and Human Rights Centre: Dar es salaam.

Legal and Human Rights Centre, The Human Rights Report of Tanzania Mainland, 2010, Legal and Human Rights Centre: Dar es salaam.

\section{INTERNET MATERIALS}

Bertelsmann Stiftung, Tanzania Country Report, https://www.bti-project.org/fileadmin/files/BTI/Downl oads/Reports/2016/pdf/BTI_2016_Tanzania.pdf last accessed on 15/08/ 2016.

Judiciary of Tanzania, Taarifa ya Mwaka ya Utekelezaji wa Majukumu Ya Mahakama Mwaka wa Fedha 2014/15 ya Tarehe 30 October, 2015, http://www.judiciary.go.tz/wp-content/uploads/2016/08/T AARIFA-YA-MWAKA-YA-UTEKELEZAJI-2014.15-KATTANGAH-VERSION.pdf (last accessed on 15/08/2016). 
Robert V. Makaramba, The Practical and Legal Challenges of Justice Delivery in Tanzania: Experience from the Bench, www.comcourt.go.tz/comcourt/?wpfb_dl=37 (last accessed on 14/08/2016).

Rachel Ellet, Judicial Independence Under the APRM: From Rhetoric to Reality, Occassional Paper, 2015, 212, http://www.saiia.org.za/occasional-papers/756-judicial-independence-under-the-aprm-f rom-rhetoric-to-reality/file (last accessed on 20/08/2016].

Tundu Lissu, A statement on various issues regarding the Tanzanian judiciary, 2012, http://www.jamhu rimedia.co.tz/ripoti-maalumu/ (last accessed on 19/08/2016).

\section{LEGISLATIONS}

Labour Institutions (Mediation and Arbitration) Rules, 2007, Government Number 7 of 2004. 